\title{
Patronage of the Bible in Sixteenth-Century Spain: A Defence of the Faith or an
}

Attack on Heresy? ${ }^{1}$

María Teresa Ortega-Monasterio

ILC-CSIC

E-Mail: maite.ortega@cchs.csic.es

Early sixteenth-century Spain offers a particularly interesting framework for analysing the interest awakened by Bible studies and its patronage by the monarchy on the threshold of the early modern period. At that time, the Spanish Empire was approaching the period of its greatest splendour, the reign of Philip II, and there existed a series of issues of particular importance for its rulers. The main issue can be said to have been that of the defence of the faith, one of the pillars of a monarchy which had fought for several centuries to wrest peninsular territory from the last Muslims. The Catholic monarchs, after the conquest of Granada and the unification of their peninsular territories, made every effort to consolidate their kingdom by reinforcing the security of their policy. One of the most outstanding features of this strategy was a defence of the Catholic faith, and to this end a series of actions was undertaken with the aim of strengthening Christianity. The final years of the fifteenth century and the first years of the sixteenth represent an age of transition in which it became clear that the Catholic Church was in need of reform, aimed at building on principles that would go further towards satisfying believers, who longed to distance themselves from routine and find new forms of spirituality. Such reforms had been discussed at the Council of Constance in the early fifteenth century, where the need for a total reform of the Church had been made apparent. The universities were to play an important role in this task.

${ }^{1}$ Published in E. Alfonso and J. Decter (eds.), Patronage, Production, and Transmission of Texts in Medieval and Early Modern Jewish Cultures, Brepols, XV+383 p., 35 b/w ill., 3 b/w tables, 156 x 234 $\mathrm{mm}, 2014$. 


\section{Cardinal Cisneros and his milieu}

One of the men trusted by the Catholic Monarchs to carry out this work of consolidation was Cardinal Cisneros. Between June 1507 and 1508 Cisneros was Inquisitor General in addition to being cardinal. This was a post which then had great social and cultural power as a result of its dependence on the Crown, and this meant that he also had important civil powers. Cisneros’s household saw a notable increase in its number of advisers, chaplains, personal guards, pages, etc. during this period. He is generally considered to have had a new concept of the state, a modern concept which contrasted with the traditional and still medieval one attributed to the future Charles . $^{2}$ From this perspective, the most relevant aspect for the present study is the importance acquired by his secretaryship and the humanistic academy based in Alcalá, from which the Complutensian Polyglot Bible would emerge. In his role as an Inquisitor he faced the difficult task of devolving their institutional role to the Council and the tribunals. In order to carry this out he employed new collaborators and sought to unify criteria for punishments by issuing instructions of a catechetic nature for the redeeming of some sentences. ${ }^{3}$ Cisneros left a very positive stamp on the Spanish Inquisition, which under him acted differently than during the immediately preceding period. This was because of the important role granted to humanism and culture in combating attacks on the faith: Cisneros protected intellectuals like Nebrija, he achieved the aim of making the tribunals respect legal procedure, and he elaborated a legal norm requiring all

\footnotetext{
${ }^{2}$ See Joseph Pérez, La hora de Cisneros (Madrid: Complutense, 1995).

${ }^{3}$ For further information on his role as Inquisitor, see José García Oro, Cisneros: El Cardenal de España (Barcelona: Ariel, 2002), pp. 169-183, and Cisneros: Un cardenal reformista en el trono de España (1436-1517) (Madrid: La esfera de los libros, 2005), pp. 127-58.
} 
Inquisitorial actions to be recorded and appropriately filed. ${ }^{4}$ In other words, he made the institution one of a public character with humanistic overtones, thereby improving its standing and the general trust placed in it.

Cisneros had had several previous contacts with humanism. In Salamanca he was able to follow the intellectual controversies of the day, and he became familiar with the proposals of reformers and the reactions they provoked. There can be little doubt that the period of time he spent in Sigüenza from 1476 onwards, at the home of the Mendoza family, made it possible for him to enter into a very specific circle of humanists, where he came to know of the project of Cardinal Mendoza's secretary, Juan López de Medina, who proposed to create an academy for the joint teaching of grammatical studies, arts and theology. During this period in Sigüenza he was able to become familiar with the problem of co-existence between Jews and Christians, witnessing at close hand the campaigns encouraged by Cardinal Mendoza which had as their aim the conversion of the Jews of Seville. Some authors have concluded that Cisneros had no significant contact with the Jews of the city, nor with their exegetical writings or the Hebrew language itself; others, such as Alvar Gómez de Castro, ${ }^{5}$ are of the view that Cisneros may be considered to have studied the language, although their claim has yet to be proven conclusively. ${ }^{6}$ However, some trace of his relations with Jews seems to have survived from this period for, as we will see, he was later to request

\footnotetext{
${ }^{4}$ In fact, criticism of Erasmus's works in Spain occurred within a much less reactionary climate than in other countries, such as France. See Marcel Bataillon, Erasmo y España.: Estudios sobre la historia espiritual del siglo XVI (México: Fondo de Cultura Económica, 1966), pp. 154-65.

${ }^{5}$ Alvar Gómez de Castro, De las hazañas de Francisco Jiménez de Cisneros (Madrid: Fundación Universitaria Española, 1984), p. 35.

${ }^{6}$ See García Oro, Cisneros: El Cardenal de España, 45, and Cisneros: Un cardenal reformista, pp. 4449.
} 
a large number of Hebrew manuscripts and the collaboration of rabbinical experts in his work. We should not forget that, among the significant factors contributing to the development of Christian Hebraism from this period onwards, there was an increase in the use of Jewish literature by educated Christians and the development of the printing press, with all that this implied for the diffusion of texts that may have been heretical from the point of view of the Catholic Church. ${ }^{7}$ Until that time, contacts between the rabbinical schools and Christian commentators had been scarce, and each of these schools had its own independent process of development, in spite of the recommendations made at the Council of Vienna of 1311. From the fifteenth century onwards, and under the influence of Renaissance tendencies, rabbinical knowledge started to be taken into account and used in works drawn up by Christians. Such works highlighted issues referring to the text of the Bible which were new to Christian scholars, but which had been widely discussed by Jewish commentators. ${ }^{8}$

\footnotetext{
${ }^{7}$ For the development of these ideas and a wide-ranging view of the subsequent censorship of texts, see Amnon Raz-Krakotzkin, 'Censorship, Editing and the Reshaping of Jewish Identity: The Catholic Church and Hebrew Literature in the Sixteenth Century', in Hebraica Veritas? Christian Hebraists and the Study of Judaism in Early Modern Europe, ed. by Allison P. Coudert and Jeffrey S. Shoulson (Philadelphia: University of Pennsylvania Press, 2004), pp.125-55. This author rightly emphasises the importance of discovering that which is eliminated from texts by censorship rather than what is preserved.

${ }^{8}$ For Frank E. Manuel, the 're-discovery' of Judaism in the fifteenth century ran parallel to the rediscovery of the classics and involved the same circles of power: printing presses, libraries, universities and patronage systems. See Frank E. Manuel, ‘Christendom’s Rediscovery of Judaism’, Bulletin of the American Academy of Arts and Sciences, 40, no. 7 (1987), pp. 15-32. However, this author fails to take into account the editions of the two polyglot Bibles and excludes Spain from the list of those nations with an interest in Hebrew studies. See Frank E. Manuel, The Broken Staff: Judaism through Christian Eyes (Cambridge, MA: Harvard University Press, 1992), p. 4. This and others of Manuel's opinions have been successfully disproved by several authors, including Stephen G. Burnett. See his 'The Broken Staff:
} 
As an Inquisitor, one of Cisneros's main tasks was to use the writings of Jewish authors sparingly and suppress in them anything that might be considered hazardous for the Catholic religion, in order to prevent the spread of possible heresies. The Latin translations of some texts came to be prohibited, ${ }^{9}$ but not the original Hebrew versions, and this seems to suggest that the prohibitions were designed with Christians rather than Jews in mind — by impeding access to certain writings, the Church was adopting a notably protectionist stance towards its flock. The role played by Cisneros in this task was an unusual one, for he managed to combine the two perspectives and interests, taking trouble to give the Jewish vision through the conversos he brought into his team.

In 1495 Cisneros was transferred to Toledo and demonstrated total loyalty to the Spanish monarchy by collaborating in its struggle against enemies of the faith, as well as in his missionary work. From this time on, his projects included the idea of creating a city devoted to the cultivation of various branches of knowledge, in the full awareness that the monarchy also favoured the creation of schools. To this effect, he struggled to achieve independence from Salamanca, then home to the most important university in the Hispanic kingdoms. However, the traditional ideas defended by the scholars at the University of Salamanca were to a certain extent obsolete for anyone seeking to take into account the social realities of the sixteenth century. Neither did Seville appear to be Judaism through Christian Eyes; Frank E. Manuel (Review)’, The Sixteenth-Century Journal, 24, no. 4 (1993), pp. 937-938.

${ }^{9}$ Cisneros went so far as to prohibit the publication of the opinion of Diego López de Zúñiga, who had described Erasmus's annotations to the New Testament as irreverent and questionable from a doctrinal point of view. Cisneros's view was that such polemical discussions between Christian scholars prevented the progress of biblical studies. Diego López de Zúñiga eventually managed to publish his ideas after the death of Cisneros. See Erika Rummel, Biblical Humanism and Scholasticism in the Age of Erasmus (Leiden: Brill, 2008), p. 5. 
the most appropriate location. Eventually, Alcalá de Henares was chosen as the headquarters for Cisneros's humanist project, and it was there that the Colegio de San Ildefonso was founded. ${ }^{10}$ The laws and norms governing Alcalá were based on the previous experience of universities like Louvaine, Paris, Bologna and Salamanca, but it was imbued with a very different spirit from that of the latter institution. Alcalá came to represent, in the words of Otis H. Green, 'the rebirth of Christian antiquity'. ${ }^{11}$ Marcel Bataillon for his part wrote that Alcalá was 'an innovative university, above all because of its faculty of theology' and emphasised that it was theology that determined the general thrust of the university’s activity. ${ }^{12}$

Of the colleges at Alcalá, it was that of theology which was the most advanced, because of the influence of currents of foreign thought, mainly Erasmism. On occasions, the college became an object of concern to the Inquisition because of the advanced nature of its ideas. The creation of the Colegio Trilingüe was a new means of renovation, with its chairs of Bible studies and Morality.

\section{The Project of the Polyglot Bible}

\footnotetext{
${ }^{10}$ For further information on the Colegio de San Ildefonso and the creation of the University of Alcalá, see, for example, Antonio Alvar Ezquerra, La Universidad de Alcalá de Henares a principios del siglo XVI (Alcalá de Henares: Universidad de Alcalá de Henares, 2008); Roberto González Ramos, La Universidad de Alcalá de Henares y las artes: El patronazgo artístico de un centro del saber, siglos XVIXIX (Alcalá de Henares: Universidad de Alcalá de Henares, 2007); José García Oro, La Universidad de Alcalá de Henares en la etapa fundacional, 1458-1578 (Santiago de Compostela: Independencia Editorial, 1992).

${ }^{11}$ Otis Howard Green, 'A Critical Survey of Scholarship in the Field of Spanish Renaissance Literature, 1914-1944', Studies in Philology, 44, no. 2 (1947), p. 240.

${ }^{12}$ Bataillon, Erasmo y España, p. 16. It is important to note the absence of law studies among the disciplines offered at Alcalá.
} 
It was within this general framework that the academic project of the Complutensian Polyglot Bible was carried out, as a response to the demands of the most recent European humanism, in which the axis of theology was represented by the Bible. This was Cisneros’s greatest personal and humanistic project and for it he gathered around him the specialists he considered most suited to the task. As we have already seen, the idea of completing this work had been in his mind for some time, and he conceived of it not only as a basis for defending the Christian faith by using the original texts of the Bible — a truly original and advanced accomplishment for that period — but also as a way of attacking heresies which might arise in the course of the wideranging debates that took place in the heart of humanist currents in general, and in that of the Erasmists in particular. The ennoblement of theology by means of humanism was one of the characteristics of Cisneros's way of thinking, and he made great efforts to achieve it in Alcalá and his biblical project. Indeed, Cisneros’s ideas and the support to them given by the king represent an important progress in the way the textual study of the Bible is developed in comparison with the kind of study carried out during the Middle and Early Modern Ages. The consequences of this progress will last until the end of the seventeenth Century, with the publication of other Polyglots ${ }^{13}$.

\section{[Figure 1]}

Specialised training in biblical and rabbinical studies would provide better and more solid arguments to rebuff possible heresies. For Cisneros there was thus a connection between editing the Polyglot Bible and bringing about the kind of renewal of the Church desired by the humanists, and this could be made plain by ensuring that the text of the new Bible was based for the first time on the original languages in which the Scriptures had been written: Greek, Latin, Hebrew, Aramaic etc. We should bear in

\footnotetext{
${ }^{13}$ Antwerp Polyglot, edited by Arias Montano (Antwerp, 1569-1573), Paris Polyglot, edited by G.M,. Le Jay (Paris, 1629-45) and London Polyglot, edited by Brian Walton (London, 1655-57).
} 
mind that his role as Inquisitor had provided him with inside knowledge of that institution, and that this made him acutely aware of the kind of issues which could be considered important in the rebuttal of any kind of accusation it brought against an individual. It was a project he carried out at the end of his life, after occupying a series of posts in the service of the Crown, and his career as a priest was at its zenith. This was a time when he was able to act as a patron and persuade the monarchy to support his undertaking. According to some authors, Cisneros's patronage has remained for all posterity as the most enduring feature of his career. ${ }^{14}$ The Polyglot Bible was, in the words of García Oro, ‘the doctrinal fortress of Catholicism' ${ }^{15}$ It became the forum for theological discussions with Lutherans and Erasmists, and it was the most important editorial project of the sixteenth-century Spanish monarchy, which had its continuation in 1567 with the Biblia Regia or Antwerp Bible edited by Arias Montano. Cisneros was the greatest patron the University of Alcalá has ever had.

Cisneros's work had its forerunners in other similar works. It is unanimously accepted that he thought of it as an imitation of Origen's Hexapla, and there is no doubt that this is true. However, other authors ${ }^{16}$ have emphasised its link with the first humanist polyglot work to be printed in Europe, the Psalter of Agostino Giustiniani, published in Genoa in 1516 by Pietro Porro. ${ }^{17}$ This work was edited in eight columns, including, unlike the Complutensian and Antwerp polyglot texts, an Arabic translation alongside the Hebrew, Aramaic, and Greek columns, as well as its three Latin versions.

\footnotetext{
${ }^{14}$ García Oro, Cisneros: Un cardenal reformista, p. 319.

${ }^{15}$ García Oro, Cisneros: El Cardenal de España, p. 359.

${ }^{16}$ See, for example, Robert J. Wilkinson, The Kabbalistic Scholars of the Antwerp Polyglot Bible (Leiden: Brill, 2007).

${ }^{17}$ Agostino Giustiniani (1479-1536) was a great collector of Oriental manuscripts. There is a copy of this Psalter in the New York Public Library, Rare Books Division.
} 
However, there are profound differences between this work and that of Alcalá: no Jewish or converso scholars took part in its composition; only the Psalter was ever published, despite the fact that the prologue announced the rest of the Bible including the New Testament; and the typesets used for the Hebrew text are of lesser quality than in that of the Complutensian Polyglot.

\section{Philip II: His defence of Christianity and Arias Montano}

Throughout the sixteenth century, so marked by continued religious diatribes between humanists, political history was also to follow a new path. Until that time, politics had taken trouble to separate the different fields in which power could be exercised. Foreign affairs were not mixed with domestic policy, or with affairs relating to the institutions or of a religious nature; each problem was kept restricted to its own environment. However, from this period onwards, and especially from the reign of Philip II, political affairs were to be treated in a more global manner, as Royal interventions were transformed. It can be said that the Counter-Reformation was an essential element in this change, and that its origins lay in the previous period, i.e. that of Cisneros. Rulers began to look for figures with the same sort of wide vision, and it was in this context that Benito Arias Montano appeared. ${ }^{18}$ During all his time in the service of the Crown,

\footnotetext{
${ }^{18}$ There is an extensive bibliography on Arias Montano and his work. See, for example, Ben Rekers, Arias Montano (Madrid: Taurus, 1973); Anatomía del Humanismo, Benito Arias Montano, 1598-1998: Actas del Simposio Internacional celebrado en la Universidad de Huelva del 4 al 6 de Noviembre de 1998, ed. by Luis Gómez Canseco (Huelva: Universidad de Huelva, 1998); Luis Morales Oliver, Arias Montano y la política de Felipe II en Flandes (Madrid: Voluntad, 1927); Emilia Fernández Tejero, 'Dos tratados de Benito Arias Montano’, in Biblia y humanismo: Textos, talantes y controversias del siglo XVI español, ed. by Natalio Fernández Marcos and Emilia Fernández Tejero (Madrid: Fundación Universitaria Española, 1997), pp. 170-73; Natalio Fernández Marcos, ‘De los nombres de Cristo de Luis
} 
but especially during the years he spent in the Netherlands, Arias Montano, as an intimate of the king, adopted a conciliatory attitude and made politics an important element in the development of his work. His service of the king was above all else to him, ${ }^{19}$ but he carried it out in a humanist spirit, considering the Royal figure the basis of both political and religious order, a truly representative model of the Hispanic monarchy. This idea was not new; having already been seen in the times of Charles V, but it was undoubtedly consolidated under Philip II. In other words, the work of Arias Montano which interests us here, the Polyglot Bible of Antwerp or Biblia Regia, must be considered part of a set of interventions aimed to consolidate the monarchy and the new imperial notion of the king. In order to show his interest in the task and patronage of it, Philip II wrote to the Duke of Alba:

Por lo que os diré el Doctor Arias Montano [...] y por la instrucción que le he mandado dar [...] entenderéis el efecto para que le envío a esos Estados, que en sustancia es para

de León y De Arcano Sermone de Arias Montano’, Biblia y humanismo, ed. by Fernández Marcos and Fernández Tejero, pp. 133-51.

${ }^{19}$ Such obedience is made plain on several occasions, including in the following letter, when he states: 'De estas tres cosas o hazer este viaje o quedar aqui o tornar ay, v. m. encomendandolas a Dios escoja la que le pareciere mejor, y encaminela que yo en todo me remitto a v. m. Esto respondo obedeciendo a lo que v. m. me manda'. ('Of these three options, that of making this journey or staying here or returning there, let it please Your Majesty to choose that which you think best after commending to God and make that choice for I will obey in all that Your Majesty decides. My answer is to obey whatever Your Majesty orders me to do’] (Archivo General de Simancas [hereinafter AGS], Estado 583, fol. 40, 18 April 1574, Arias Montano to Zayas); or in another: 'Desde entonces le he suplicado y suplico me de gracia para que yo emplee la vida que me dejara en su servicio y en el de V. M.'. ('Since then I have begged and beg for the grace to be able to employ the life given to me in his service and in that of Your Majesty’) (AGS, Estado 583, fol. 19, 9 May 1570, Arias Montano to Philip II). 
que intervenga y asista a la impresión de la Biblia cuadrilingüe [... y y por tanto, habiéndose dispuesto Cristoforo Plantino, impresor y mercader de libros en Anvers a la querer renovar e imprimir de nuevo con muy buenos caracteres de todas lenguas debajo de nuestro nombre, amparo y autoridad. ${ }^{20}$

('I will tell you of Doctor Arias Montano [...] and the instructions I have given him [...] so that you will understand the reason why I am sending him to those States, which in essence is so that he may intervene and assist in the printing of the quadrilingal Bible [...] and therefore, having arranged for Christophe Plantin, printer and book merchant of Antwerp to renew and re-print with very good characters in all the languages beneath our name, protection and authority').

Arias Montano’s idea was to combine obedience to the king with the salvaging of Flanders as part of Spain, and for this reason he made constant efforts to bring about its pacification. ${ }^{21}$ When the Duke of Alba was replaced by Requesens, Montano's ideas became more influential, despite the fact that he had supported Alba: their aims were united and repressive measures against dissidents were softened. Indeed, the king adopted the habit of sending Montano's opinions to Requesens so that they would be taken into account. For Montano, it was the king's responsibility to maintain the

\footnotetext{
${ }^{20}$ AGS, Estado 583, fol. 202, 25 March 1568, Philip II to the Duque of Alba.

${ }^{21}$ In a letter dated 27 February 1573, Montano tells Zayas, the king’s secretary, that he has begged the king 'Recobre los corazones destos sus vasallos, y que mande a sus ministros que entiendan en esto muy de propósito' ('To regain the hearts of these his vassals, and to tell his ministers to understand this fully'). He later states that if this is not done, many lives will be lost. See Colección de Documentos Inéditos para la Historia de España, ed. by Martín Fernández Navarrete and others, 113 vols (Madrid: Imprenta de la viuda de Calero, 1842-95), XLI, p. 290 (hereinafter CODOIN).
} 
Catholic faith in his territories. In a letter to Gabriel de Zayas dated 5 February 1571, he wrote:

La persona principal entre todos los príncipes de la tierra que por experiencia y confesión de todo el mundo tiene Dios puesta para sustentación y defensa de la Iglesia Católica es el rey don Felipe. ${ }^{22}$

('The principal person among all the princes of the Earth who for experience and confession of all the world has been placed by God for the sustenance and defence of the Catholic Church is the king Don Philip’).

Some authors have argued for the political connotation of a number of Arias Montano’s works, holding that for any publication made in that period in the Netherlands a separation cannot be made between the religious and political character of the work. ${ }^{23}$ It is quite likely that any work coming from a Royal adviser would to some extent have been designed to influence in a global fashion the thoughts of those to whom it was directed.

Proof of the intentions with which the Bible was made and the auspices under which it was carried out is provided by Arias Montano himself, in his first preface:

Dios [...] también consiguió que en nuestros días, para que una cuestión de tanto peso e importancia [...] llegara a una situación crítica, animó la intención de Felipe II [...] para

\footnotetext{
${ }^{22}$ CODOIN, XLI, 206.

${ }^{23}$ This is the theory held by Sánchez Lora, whose idea is nonetheless opposed by Ángel Alcalá. See José Luis Sánchez Lora, Arias Montano y el pensamiento político en la corte de Felipe II (Huelva: Universidad de Huelva, 2008), p.109.
} 
que entre las muchas acciones que ha emprendido, asumido con valentía, y muy felizmente realizado en beneficio de la Iglesia sacrosanta [... y en definitiva a favor de toda la cristiandad, también decidió que se hiciera una edición por la comparación de los libros sagrados en las lenguas antiguas y con sus mejores versiones. ${ }^{24}$ ('God [...] also brought it about that in our days, so that a question of such weight and importance [...] should come to a critical situation, the intention of Philip II was moved [...] so that among the many actions he has undertaken, assumed with courage, and very happily carried out to the benefit of the sacrosanct Church $[\ldots]$ and, in sum, to the favour of all Christendom, he also decided to have made an edition through the comparison of the sacred books in the ancient tongues and in their best versions').

The king's patronage is also displayed in an introductory engraving to the edition, in an inscription which reads: 'Philippo II in Hispania. Regi Catholico, quod religionem expiandam pietatemq. instauranda curaverit pos’. ('To Philip II, catholic King of Spain, who took pains to purify religion and restore piety').

One of the individuals who supported Arias Montano most firmly in his ideas was Lipsius, regarded by Montano as an excellent friend, ${ }^{25}$ and who played an important role in the Biblia Regia project. The use of biblical texts was fundamental for both men in the development of their political theories, and both took the Book of Joshua as a model on several occasions, comparing his struggle with that of the king in defence of religion. Lipsius understood patronage as one of the several duties to be done by rulers. As a result, they were obliged to undertake actions designed to maintain

\footnotetext{
${ }^{24}$ Benito Arias Montano, Prefacios de Benito Arias Montano a la Biblia Regia de Felipe II, ed. by María Asunción Sánchez Manzano (León: Universidad de León, 2006), p. 39.

${ }^{25}$ Sánchez Lora, Arias Montano, 44 reproduces two fragments of a letter from Arias Montano to Lipsius, dated 1593 and sent from Seville.
} 
their subjects in the true faith. This right to patronage was undoubtedly exercised by Philip II during his reign, as is seen in undertakings such as the composition of the Polyglot Bible of Antwerp, considered one of the greatest academic and editorial achievements of the sixteenth century.

\section{The two polyglot Bibles: Similarities, differences and patterns}

If the Complutensian Polyglot is considered one of the greatest humanist undertakings of the reign of the Catholic Monarchs, the same can be said of the Antwerp Polyglot in the reign of Philip II. Both had religious motivations and were intended for the defence of the Catholic faith, but their ranges are very different. Whereas the first was produced in what was then the most powerful Spanish cultural centre, the University of Alcalá, which had recently been granted the means it needed and had a "peninsular" influence, the second was put together in Antwerp, and published by the press of Plantin in a country still belonging to the Spanish Crown but which was mired in political and religious strife, in a context teeming with controversies and attacks on Catholicism. Patronage of the Bibles was fundamental, not only for those in charge of editing them, but also for their printers. ${ }^{26}$

[Figure 2]

A printer's participation in such a project meant a significant leap in his career, and costs would never have been met if it had not been for the assistance of such

\footnotetext{
${ }^{26}$ For more details on Brocar, the printer of the Complutensian Polyglot, and his work, see Mariano Revilla Rico, La políglota de Alcalá (Madrid: Imprenta Helénica, 1917), and María Teresa OrtegaMonasterio, 'Textual Criticism of the Bible in the Spanish Renaissance', Journal of Biblical Textual Criticism, 13 (2008) <http://rosetta.reltech.org/TC/vol13/vol13.html> [accessed 15 June 2012].
} 
powerful patrons. ${ }^{27}$ Plantin himself made it clear that he was acting under royal patronage:

Tambien embio a vuestra señoría la orden de la costa y gastos que yo he hecho y queda por hazer para la impression de la Biblia en quatro lenguas, la qual yo desseo mucho imprimir debaxo del favor de su Magestad. ${ }^{28}$

('I am also sending your lordship the list of costs and expenses which I have made and have still to make for the printing of the Bible in four languages, which I have much desire to print with the favour of Your Majesty').

The king even outlined the conditions under which the work was to be carried out: Nuestro muy Sancto Padre el Papa Gregorio XIII [...] mando dar un Motu Proprio para que solo vos la pudiessedes imprimir y vender por tiempo de veinte años [...] y nos supplicasteis que acatando lo referido, nos assimismo os mandassemos dar priuilegio para que por el tiempo que fuessemos seruido, vos, o, quien vuestro poder huuiere tan solamente pudiessedes imprimir y vender en estos nuestros Reynos la dicha Biblia y los tratados del Apparato Sacro a ella añadidos [...] y nos acatando lo susudicho, y conformandonos con la voluntad y concession de su Santidad [...] lo auemos auido por

\footnotetext{
${ }^{27}$ This has been pointed out by Stephen Burnett, among others. See Stephen G. Burnett, 'Christian Aramaism: The Birth and Growth of Aramaic Scholarship in the Sixteenth Century', in Seeking out the Wisdom of the Ancients: Essays Offered to Honor Michael V. Fox on the Occasion of his Sixty-Fifth Birthday, ed. by Ronald L. Troxel, Kelvin G. Friebel, and Dennis R. Magary (Winona Lake, IN: Eisenbrauns, 2005), p. 432. Although Burnett focuses in this paper on sixteenth-century Aramaic studies, he offers interesting data on the Hebrew Bible more generally. ${ }^{28}$ AGS, Estado 583, fols 44-45, 19 December 1566, Christophe Plantin to Zayas.
} 
bien, y por la presente damos licencia y facultad a vos el dicho Christophoro Plantino para que por tiempo de veinte años primeros siguientes (que se cuenten desde el dia de la data desta nuestra cedula en adelante) vos, o quien vuestro poder huuiere y no otra persona alguna, podais imprimir y imprimais en estos nuestros Reynos y señorios la dicha Biblia y tratados del dicho Apparato sacro a ella añadidos y prohibimos y defendemos que (durante el tiempo de los dichos XX años) otras personas algunas de qualquier estado, qualidad, o, condicion que sean no puedan imprimir ni hazer imprimir, directa ni indirectamente la dicha Biblia, ni ninguna cosa ni parte della, ni del dicho Apparato, ni impressa por otros en todo ni en parte traerla de fuera a estos nuestros Reynos, ni venderla en ellos, sino tan solamente vos el dicho Christophoro Plantino, o, quien vuestro poder tuuiere, so pena de perder la tal impression, o, impressiones, y los moldes y aparejos conque la imprimieren, y mas treinta mill maravedis por cada vez que lo contrario hizieren la qual pena applicamos en esta manera: la tercia parte para nuestra camara, y la otra tercia parte para el denunciador, y la otra tercia parte para el juez que lo sentenciare'. ${ }^{29}$

('Our very Holy Father Pope Gregory XIII [...] ordered a Motu Proprio to be sent so that only you could print and sell it for a period of twenty years [...] and you begged us that, having accepted this, we should also send you the privilege for such time as we desired for you or whomsoever you wished to be able to print and sell in these our realms the said Bible and the treatises of the Holy Apparatus added to it $[\ldots]$ and you having accepted the aforesaid terms, and conforming ourselves to the will and concession of his Holiness [...] we accept it and by means of the present we grant licence and faculty to you, the said Cristophoro Plantino, so that for the period of the first twenty years hereafter — which shall be counted from the day of the date of this our order henceforth — you, or whomsoever you wish and not any other person may print in these our realms and territories the said Bible and the treatises of the said Holy

\footnotetext{
${ }^{29}$ AGS, Estado 583, fol. 149, January 1573, Philip II to Plantin, concerning the Bible.
} 
Apparatus added to it and we prohibit and defend that — for the period of the said twenty years - no other persons of any state, quality or condition whatsoever shall be able to print or order to have printed directly or indirectly the said Bible, nor any thing or part of it, nor the said Apparatus, nor shall others be able to print it entirely or in part have it brought from abroad to these our kingdoms, nor sell it within them, but only you, the said Christophoro Plantino, or whomsoever you may wish, under the punishment of losing the said printing, and the molds and devices with which the printing is carried out, and a further thirty thousand maravedis for each time that anyone should do the contrary, which fine shall be applied in the following manner: a third shall be for our chamber, another third for him who reports the crime, and the other third for the judge who should pass sentence').

\section{Although the Biblia Regia took the Complutensian as its model, Montano} specified in his prologues the most significant differences that existed between the two, highlighting above all else the importance given to Hebrew grammar. He specially quotes the importance of the accents and the vocalization of the Masoretic text:

Pues además de la belleza excelente de la forma, del papel, de los signos gráficos, esta obra añade a la Biblia Complutense las paráfrasis caldeas del Antiguo Testamento enteras, los libros de la versión siria al Nuevo, y esos examinados con diligente análisis y crítica, ilustrados con el recurso accesible de las versiones latinas, y lo que importa mucho para la distinción y explicación de las lecturas y las frases, incorporó todos los acentos y ápices hebreos (que Cristo no permitirá que se pierdan nunca) aplicados con mucha precisión. ${ }^{30}$

\footnotetext{
${ }^{30}$ Arias Montano, Prefacios, 41.
} 
('For in addition to the excellent beauty of the form, the paper, [and] the graphic signs, this work adds to the Complutensian Bible all of the Chaldean paraphrases of the Old Testament, [and] the books of the Syrian version in the New, and these have been examined with diligent analysis and criticism, illustrated by the accessible recourse of the Latin versions, and, which is very important for distinguishing and explaining the readings and phrases, it includes all the Hebrew accents and markings (which Christ will not ever allow to be lost) applied with much precision’).

Montano was forced to fight against the elements much more than Cisneros, as becomes clear in his letters and the prefaces he wrote to the Bible. For one thing, he had to cope with an illness which almost prevented him from continuing with his studies. He wrote in a letter to the king in 1570 :

Puesto que yo me tenía persuadido que llevándome Dios él sabía lo que hacía y hacía lo que a mí me cumplía, y él sabía muy bien hallar y levantar ministros más idóneos que yo pues que puede de las piedras levantar hijos a Abraham y que la obra se acabaría pues es tan santa y tan a su servicio y el mayor tesoro de sabiduría que en la tierra hay dado por beneficio suyo a los hombres para grande provecho dellos mismos y para gloria de su santo nombre. ${ }^{31}$

('For I was convinced that in taking me God knew what He was doing and did what was fit for me, and He knew full well how to find and raise up more ideal ministers than me for He was able to raise up sons for Abraham from stones. [I was also convinced] that the work would be completed for it is so holy and so much in His service; it is the greatest treasure that has been given for the benefit of men on Earth , a great advantage for them and for the glory of His holy name’).

\footnotetext{
${ }^{31}$ AGS, Estado 583, fol. 19, 9 May 1570, Arias Montano to Philip II.
} 
He gave up all of his time to the work. In a letter to Zayas, dated 9 November 1568, he states:

El Génesis está acabado, y vamos sobre el Éxodo y de esta semana en adelante metemos otra emprenta mas. A mí no me falta obra ni me sobra tiempo de manera que aún las fiestas tengo bien en que entender. ${ }^{32}$

('Genesis is finished and we are working on Exodus and from this week on we will fit in another printing. I have no lack of work and no excess of time, so that I have things to do even on holy days').

Similarly, in a letter sent to Philip II two years later, he says:

Y puesto que me sea necesario estar cada día once horas estudiando escriviendo recorriendo y visitando lo que se hace y ha de hacer y esto también las fiestas como los otros días. ${ }^{33}$

('And given that I need to spend eleven hours each day studying, writing, retracing and visiting what is being done and what has still to be done and this also on the holy days just as on the other days').

But thanks to this diligence, he managed to meet the deadlines which had been agreed:

\footnotetext{
${ }^{32}$ AGS, Estado 583, without fol., 9 November 1568, Arias Montano to Zayas.

33 AGS, Estado 583, fol. 19, 9 May 1570, Arias Montano to Philip II.
} 
Estarán cuatro cuerpos acabados dentro de quince días placiendo a Dios que no faltará en ellos más que el chaldeo de los proverbios de Salomón por el cual yo he escrito al secretario Zayas y a Alcalá de Henares para que de allí se me embie porque toda la sección ordinaria de esta Biblia quiero que vaya conforme a los exemplares de España. ${ }^{34}$

('Four blocks of text will be finished within a fortnight if God be pleased and there will be nothing lacking in them other than the Chaldean text of Solomon's Proverbs, about which I have written to secretary Zayas and to Alcalá de Henares so that from there they will send it to me for I want all of the ordinary section of this Bible to conform to the examples of Spain').

However, he also had to deal with continual economic difficulties:

Tambien supplico a vuestra Magestad como fiel criado y que con todo mi animo y honor y valor esse poco que tengo he desseado servir en todo quanto he podido, que vuestra Magestad sea servido mandar a su thesorero que antes que yo de aqui salga pague aquellas cedulas que por servicio de vuestra Magestad yo libre aqui tanto tiempo ha que nunca se han pagado por lo qual mi conciencia esta cargada y mi honor mas empeñado de lo que fuera servicio de vuestra Magestad. ${ }^{35}$

(I also beg Your Majesty as a faithful servant, with all my soul and honour and what little value I have, that I have desired to act in your service in all that I could, that Your Majesty should be so good as to send your treasurer before I leave this place to pay for those tasks which I have been performing in the service of Your Majesty. This has not been paid for

\footnotetext{
${ }^{34}$ AGS, Estado 583, fol. 19, 9 May 1570, Arias Montano to Philip II.

${ }^{35}$ AGS, Estado 583, fol. 42, 9 October 1574, Arias Montano to Philip II.
} 
such a long time and for that reason my conscience is burdened and my honour more at stake than is fit for one in Your Majesty's service’).

[Figure 3]

At the end of their projects, the editors of both Bibles, despite the royal backing for their work, had to request the Pope’s approval for the sale and distribution of their books. In both cases, this permission was slow to come and approval was only granted with some difficulty. In the case of the Complutensian, it did not arrive until 22 March 1520, after the death of Cisneros and in the case of the Antwerp Bible in 1576, after a number of serious accusations and denunciations had been made. ${ }^{36}$

To what interests do these Bibles respond? Both share some concerns: firstly, the humanist currents of the sixteenth century re-awakened interest in the Bible and, above all, in knowing the texts in their original languages. Common translations, and especially that of the Vulgate, had been attacked: their texts were corrupted because they used copies of the most readable manuscripts instead of the most reliable ones. Therefore, it became necessary to defend Christian faith based on the original text of the Bible. Cisneros himself says, in a letter to Leo $\mathrm{X}$ in which he speaks of his reasons for embarking on the publication of the Polyglot:

En primer lugar, porque ninguna versión puede trasladar fielmente toda la fuerza y propiedad del original [...] cuyas palabras están preñadas de sentidos y llenas de misterios que sólo pueden vislumbrarse o conocerse a través del original [...] añádase a esto que los manuscritos latinos de la Biblia con mucha frecuencia disienten entre sí, o hay motivos

\footnotetext{
${ }^{36}$ For more information on the approval process of the Biblia Regia, see Wilkinson, The Kabbalistic Scholars of the Antwerp Polyglot Bible, pp. 93-99.
} 
suficientes para creer que están corrompidos por la ignorancia y negligencia de los copistas. $^{37}$

('Firstly, because no version can translate faithfully all the force and propriety of the original [...] the words of which are pregnant with meanings and full of mysteries which can only be perceived or known through the original [...] add to this that the Latin manuscripts of the Bible frequently disagree with one another, or there are sufficient reasons to believe that they are corrupted through the ignorance and negligence of the scribes').

And Arias Montano, on this same question of original languages, states in his preface:

Y a esta cuestión es pertinente aquella recomendación estudiosa y diligente de las lenguas hebrea, caldea y griega [...]; éstas en parte son las originales, en parte se refieren a una interpretación y explicación de las originales muy directamente [...] comprobaron por sus testimonios que debían aprenderse y conocerse por su utilidad y casi necesariamente. ${ }^{38}$

('And that studious and diligent recommendation of the Hebrew, Chaldean, and Greek tongues is relevant to this question [...] these are in part the originals, and in part they refer to an interpretation and explanation of the originals in a very direct manner... their experience taught them that they had to learn them because they were useful and almost of necessity').

At the same time, the controversies which arose in Europe also made exact knowledge of the biblical text highly desirable, in order to be able to answer the Jews,

\footnotetext{
${ }^{37}$ Revilla Rico, La políglota de Alcalá, p. 6.

${ }^{38}$ Arias Montano, Prefacios, p. 21.
} 
especially those trained in rabbinic literature. Monarchs therefore felt obliged to sponsor projects which would help them to affirm their defence of the faith (in the case of the Catholic monarchs) or to support it (in the case of Philip II). Many authors have described Cisneros as a man ahead of his time, because of the way he foresaw the Erasmist and Lutheran currents which were to develop, ${ }^{39}$ and took an initiative of great significance for theology.

Alvar Gómez de Castro, writing of Cisneros’s great project and the lack of contemporary interest in biblical studies, even among theologians, states:

En medio de la dejadez tan alarmante de nuestros hombres, que descuidaban la Sagrada Escritura, brotarían inmediatamente personas impías, que armadas con la lectura de la Biblia, interpretada torcidamente según su gusto, intentarían atacar y destruir la Iglesia de Cristo con una osadía criminal e inhumana, que ha surgido, sin embargo, de nuestra necedad. $^{40}$

(In the midst of this alarming carelessness of our men, who neglected the Holy Scriptures, impious persons rose up and, armed with readings of the Bible twisted to suit their interpretations, sought to attack and destroy the Church of Christ with a criminal and inhuman daring, which was born, it has to be said, from our stupidity).

And Cisneros specifies in his preface:

\footnotetext{
${ }^{39}$ A good survey about Erasmus' opinions on the Church Fathers’ philosophy can be found in Christoph Burger, 'Erasmus of Rotterdam and Late Medieval Theologians on the Doctrine of Grace', in Christian Humanism: Essays in Honour of Arjo Vanderjagt, ed. by Alasdair A. MacDonald, Zweder R. W. M. von Martels, and Jan R. Veenstra (Leiden: Brill, 2009), pp. 225-34.

${ }^{40}$ Gómez de Castro, De las hazañas de Francisco Jiménez de Cisneros, p. 115.
} 
Por lo tanto, esta es la razón por la que hemos ordenado imprimir la Biblia en su lengua original con distintas traducciones [...] Para cumplir esta tarea, nos hemos visto obligados a recurrir al conocimiento de los más capacitados filólogos y a investigar en todas las direcciones, para conseguir los mejores y más antiguos manuscritos hebreos y griegos. Nuestro objetivo es resucitar el hasta ahora dormido estudio de las Sagradas Escrituras.”41

('Therefore, this is the reason why we have ordered the Bible to be printed in its original tongue with different translations [...] To fulfil this task, we have been obliged to resort to the knowledge of the most able philologists and to investigate in all directions, to obtain the best and most ancient Hebrew and Greek manuscripts. Our aim is to resuscitate the thus far dormant study of the Holy Scriptures').

As far as the Biblia Regia is concerned, Arias Montano writes in the preface cited above:

De este modo a él (al rey) se le confió de parte de Dios entre otros cuidados (que él aceptó con gran fidelidad para la salvación común y la tranquilidad de muchos pueblos) [...] el compromiso único [...] con la piedad y la religión pura, y el más firme fundamento para consolidar todo estado. ${ }^{42}$

('In this way to him [the king] was entrusted by God among other cares — which he accepted with great fidelity for the common salvation and tranquillity of many peoples - a unique commitment $[\ldots]$ to pure piety and religion, and the firmest foundation to consolidate all states').

\footnotetext{
${ }^{41}$ James Patrick R. Lyell, Cardinal Ximenes: Statesman, Ecclesiastic, Soldier and Man of Letters; With an Account of the Complutensian Polyglot Bible (London: Grafton, 1917), p. 27.

${ }^{42}$ Arias Montano, Prefacios, p. 39.
} 
Edition of the Complutensian Bible relied on Cisneros's support for the text of the Vulgate, at the same time that an interest was shown in older versions. In the prologue, Cisneros cites Nicholas of Lyra, and explains to Pope Leo X that the text of the Vulgate prevails in those cases where there is a divergence from the original Hebrew or Greek. However, by offering original texts at the same time, their interpretation is left open, while the differences between the texts are displayed. The main difference between Cisneros and Erasmus can be seen in the New Testament, for this is where Erasmus placed the greatest emphasis in his writings. Erasmus was not interested in the Old Testament to the same extent, for he knew no Hebrew. By contrast, one of the strongest points of the Complutensian Bible lies precisely in its Hebrew text. The specialists in charge of it were conversos and their background enabled them to know very well how to choose the manuscripts on which to base the final text. Arias Montano also explained that the manuscripts used were the best he had been able to gather:

Los hemos tomado, no sin esfuerzo, de los mejores manuscritos (no sólo a nuestro parecer, sino que son los más aceptados por muchos especialistas) que han llegado a nuestras manos. ${ }^{43}$

('We have taken them with no little effort from the best manuscripts — not only in our opinion, but those accepted as such by many specialists — which have reached our hands').

\section{Working teams: The authors of the texts}

\footnotetext{
${ }^{43}$ Arias Montano, Prefacios, p. 51.
} 
The incorporation of new ideas to defend the faith allowed Cisneros to show his timeliness by using conversos in his work. There is no doubt that the Jewish background of the conversos who collaborated in the edition of the polyglots was decisive in introducing Jewish sources used to demonstrate the enduring validity of the true Christian faith. Both Bibles, the Complutensian and the Regia/Antwerp, display similarities in the way they were put together. Both enjoyed royal patronage, both focused on a person who led the enterprise, and both saw the formation of very complex working teams.

Cisneros did not limit himself to being the patron of the Alcalá Polyglot project. He followed and supervised the work very closely, as can be seen from his agreements and disagreements with some of those involved. Such was the case of Antonio de Nebrija, to whom Cisneros decided to give a leading role until he withdrew from the project, or a series of scholars from Alcalá who specialised in Greek, Latin and Hebrew. ${ }^{44}$ Cisneros displayed a keen eye for the future by employing conversos, who brought crucial rabbinical knowledge to the project when it came to choosing and establishing texts. Bataillon was even inclined to believe that the development of Nebrija's thought was influenced by intellectual exchange with Jews or individuals with a Jewish background. ${ }^{45}$ Although efforts were made to limit the activities of the conversos, there was a general attempt to bring them into certain positions with the intention of re-inserting them in society. Cisneros's attitude can be seen as a part of this

\footnotetext{
${ }^{44}$ For a more detailed description of this team and of Alfonso de Zamora, see María Teresa OrtegaMonasterio, 'Las bibliotecas y sus manuscritos hebreos', in Catálogo de Manuscritos Hebreos de la Comunidad de Madrid, ed. by Javier del Barco, Serie A: Literatura Hispano-hebrea, 3 vols (Madrid: CSIC, 2003-06), I (2003), pp. 15-55; and 'Un tesoro catalogado’, in Del Barco, Catálogo de Manuscritos Hebreos de la Comunidad de Madrid, III (2006), pp. 19-53.

${ }^{45}$ Bataillon, Erasmo y España, p. 26.
} 
policy — which turned out to be largely unsuccessful — because he saw the tremendous advantages of bringing certain conversos with excellent humanistic and biblical training into the project. The clearest examples were those of Pablo Coronel, Alfonso de Alcalá and Alfonso de Zamora. The last of these was a Hebrew professor at the University of Alcalá, and much of his manuscript work has survived, such as his interlineal Hebrew and Latin versions of Genesis (San Lorenzo de El Escorial, Real Biblioteca [RBSL], MS G-I-4), which coincides with Madrid, Biblioteca Histórica de la Universidad Complutense de Madrid, MS 11; RBSL, MS G-I-12, which contains Later Prophets and Hagiographa and carries annotations of chapters and words omitted in the handwritten text of Alfonso de Zamora; RBSL, MS G-I-5 is also in his hand and contains the names of the biblical books and divisions by chapters with their corresponding enumeration, in red ink. RBSL, MS G-II-18 is entirely written by Alfonso de Zamora, who is also the author of the translation on its first eleven folios. In RBSL, MS G-IV-12 he notes on the recto sheet of the first folio the title of the codex in Hebrew and on fol 106 he writes the colophon, in which he explains what he has added to the codex, and specifies the place and date of its composition — Alcalá de Henares, 1534. He also gives the same location and a date for the copy that was made -14 December 1519 - in one of the colophons of RBLS, MS G-II-5; in another colophon he says that it was copied by him for 'the illustrious Diego López de Zúñiga, with the permission of Don Fray Francisco Jiménez, Cardinal of Spain, Archbishop of Toledo’. All of their work took place between 1502 and 1517, the year in which Cisneros died, before Papal authorisation was finally obtained in $1520{ }^{46}$

\footnotetext{
${ }^{46}$ For details on the printing of copies of the Bible and their costs, see Revilla Rico, La políglota de Alcalá, pp. 43-48. Details on the copies made, and the typesets used by the presses for Greek and Hebrew can also be found in Lyell, Cardinal Ximenes. Lyell wrote that there were forty nine copies of the
} 
The Polyglot Bible of Antwerp was also the result of wide-ranging teamwork. Arias Montano was designated by Philip II to carry out the work; he moved to Flanders and directed the project from there, at Plantin's workshop and with the assistance of specialists like Guillaume Postel, Andreas Masius and Guy Lefèvre de la Boderie. In his prologue, Arias Montano presents these men as the most accredited and honoured collaborators, praising their efforts in the composition of the work. ${ }^{47}$ It is through them and the circles that they frequented that Montano's name is related with the Familia Charitatis, with the claim sometimes being made that it had a direct effect on the production of the Bible. However, there is insufficient reason to suppose that the Bible was a product of their influence. ${ }^{48}$

However, a great deal has been said about the connection between the Bible and the Kabbalah in another respect. Arias Montano’s treatise De arcano sermone has been described as kabbalistic, because of the way it tries to find the arcane sense of words and meanings. ${ }^{49}$ The sixteenth-century northern Europeans who devoted themselves to biblical studies were clearly marked by much stronger kabbalistic currents than their

Complutensian Polyglot in England (more than twenty of them in Oxford and Cambridge), four in Scotland, sixteen in the U.S.A., nine in France, eight in Italy, seven in Germany, two in Portugal, two in Spain and one in Denmark, Holland, Switzerland and Russia. These figures do not coincide with those given in Revilla Rico, La Políglota de Alcalá, pp. 43-45.

${ }^{47}$ Montano describes Lefèvre as an illustrious poet and a noteworthy, intelligent, devout and excellent connoisseur of the Hebrew and Syriac tongues. He also praises Lefèvre’s brother Nicholas, Plantin, and other collaborators. See Arias Montano, Prefacios, pp. 57-61.

${ }^{48}$ For further information on this point, see Wilkinson, The Kabbalistic Scholars of the Antwerp Polyglot Bible, pp. 28-33.

${ }^{49}$ For this treatise by Arias Montano and the secret language of the Scriptures, see Natalio Fernández Marcos, 'La Polémica en torno a la Biblia Regia de Arias Montano’, Biblia y humanismo , ed. y Fernández Marcos and Fernández Tejero, pp. 229-38. 
southern counterparts, especially those from Spain. But Montano already had a special predisposition to interpret texts in both a literary and mystical way. It was for this reason that he approved of the opinions of his colleagues Masius, Boderie and Postel, even though this led him into great difficulties with some Spanish scholars, such as León de Castro.

\section{Conclusion}

This presentation and study of the two greatest editorial projects of the sixteenth century in the biblical field demonstrate that both resulted from an initiative and patronage that came directly from the king or his immediate entourage. This was a circumstance that was not to be repeated for many years. The tasks of production were placed in the hands of men who enjoyed the absolute trust of the king, who was able to direct them throughout the process. These editorial projects were intended to promote and defend the Christian faith. In addition, these editions re-established the importance of the original texts of the Bible, on the basis of the producers' knowledge both of Christian patristics and Jewish classical sources, which contributed significantly to the scientific standing of the works. Moreover, the works served as tools for refuting and attacking defendants before Inquisition tribunals, given the exceptional information on Jewish practices that they were able to provide based on the various manuscripts used in the composition of the Bibles. In spite of the difficulties they endured in obtaining final Papal approval, the mark they have left on biblical studies in Spain has remained over several centuries and the books continue to be a point of reference in the transmission of the text of the Hebrew Bible.

\section{Works Cited}




\section{Manuscripts and Archival Documents}

Simancas, Archivo General, Estado 583

\section{Primary Sources}

Benito Arias Montano, Prefacios de Benito Arias Montano a la Biblia Regia de Felipe II, ed. by María Asunción Sánchez Manzano (León: Universidad de León, 2006)

\section{Secondary Works}

Alvar Ezquerra, Antonio, La Universidad de Alcalá de Henares a principios del siglo XVI (Alcalá de Henares: Universidad de Alcalá de Henares, 2008)

Bataillon, Marcel, Erasmo y España.: Estudios sobre la historia espiritual del siglo XVI (México: Fondo de Cultura Económica, 1966)

Burger, Christoph, 'Erasmus of Rotterdam and Late Medieval Theologians on the Doctrine of Grace', in Christian Humanism: Essays in Honour of Arjo Vanderjagt, ed. by Alasdair A. MacDonald, Zweder R. W. M. von Martels, and Jan R. Veenstra (Leiden: Brill, 2009), pp. 225-34

Burnett, Stephen G., 'Christian Aramaism: The Birth and Growth of Aramaic Scholarship in the Sixteenth Century', in Seeking out the Wisdom of the Ancients: Essays Offered to Honor Michael V. Fox on the Occasion of his SixtyFifth Birthday, ed. by Ronald L. Troxel, Kelvin G. Friebel, and Dennis R. Magary (Winona Lake, IN: Eisenbrauns, 2005), p. 421-436

—, 'The Broken Staff: Judaism through Christian Eyes; Frank E. Manuel (Review)', The Sixteenth-Century Journal, 24, no. 4 (1993), pp. 937-938 
Coroleu, A., 2008, «Erasmism in Spain», in Rummel, E., Biblical Humanism and Scholasticism in the Age of Erasmus, Brill, Leiden, 73-92Fernández Marcos, Natalio, ‘De los nombres de Cristo de Luis de León y De Arcano Sermone de Arias Montano’, Biblia y humanismo: Textos, talantes y controversias del siglo XVI español, ed. by Natalio Fernández Marcos and Emilia Fernández Tejero (Madrid: Fundación Universitaria Española, 1997), pp. 133-51

_,'La Polémica en torno a la Biblia Regia de Arias Montano’, in Fernández Marcos, N. and Fernández Tejero, E. (ed.) Biblia y Humanismo, Textos, talantes y controversias del siglo XVI español, Madrid, 1997, pp. 229-238

Fernández Navarrete, Martín, and others, eds, Colección de Documentos Inéditos para la Historia de España, 113 vols (Madrid: Imprenta de la viuda de Calero, 1842-95) Fernández Tejero, Emilia, 'Dos tratados de Benito Arias Montano’, in Biblia y humanismo: Textos, talantes y controversias del siglo XVI español, ed. by Natalio Fernández Marcos and Emilia Fernández Tejero (Madrid: Fundación Universitaria Española, 1997), pp. 169-176

García Oro, José, Cisneros: Un cardenal reformista en el trono de España (1436-1517) (Madrid: La esfera de los libros, 2005)

—, Cisneros: El Cardenal de España (Barcelona: Ariel, 2002)

—, La Universidad de Alcalá de Henares en la etapa fundacional, 1458-1578 (Santiago de Compostela: Independencia Editorial, 1992)

Gómez Canseco, Luis, ed. Anatomía del Humanismo, Benito Arias Montano, 15981998: Actas del Simposio Internacional celebrado en la Universidad de Huelva del 4 al 6 de Noviembre de 1998 (Huelva: Universidad de Huelva, 1998)

Gómez de Castro, Alvar, De las hazañas de Francisco Jiménez de Cisneros (Madrid: Fundación Universitaria Española, 1984) 
González Ramos, Roberto, La Universidad de Alcalá de Henares y las artes: El patronazgo artístico de un centro del saber, siglos XVI-XIX (Alcalá de Henares: Universidad de Alcalá de Henares, 2007)

Green, Otis Howard, ‘A Critical Survey of Scholarship in the Field of Spanish Renaissance Literature, 1914-1944’, Studies in Philology, 44, no. 2 (1947), pp. $228-264$

Lyell, James Patrick R., Cardinal Ximenes: Statesman, Ecclesiastic, Soldier and Man of Letters; With an Account of the Complutensian Polyglot Bible (London: Grafton, 1917)

Manuel, Frank E. The Broken Staff: Judaism through Christian Eyes (Cambridge, MA: Harvard University Press, 1992)

—, 'Christendom's Rediscovery of Judaism', Bulletin of the American Academy of Arts and Sciences, 40, no. 7 (1987), pp. 15-32

Morales Oliver, Luis, Arias Montano y la política de Felipe II en Flandes (Madrid: Voluntad, 1927)

Ortega-Monasterio, María Teresa, 'Textual Criticism of the Bible in the Spanish Renaissance', Journal of Biblical Textual Criticism, 13 (2008) <http://rosetta.reltech.org/TC/vol13/vol13.html> [accessed 15 June 2012]

—, 'Las bibliotecas y sus manuscritos hebreos', in Catálogo de manuscritos hebreos de la Comunidad de Madrid, ed. by Javier del Barco, Serie A: Literatura Hispanohebrea, 3 vols (Madrid: CSIC, 2003-06), I (2003), pp. 15-55

—, 'Un tesoro catalogado’, in Del Barco, Catálogo de manuscritos hebreos de la Comunidad de Madrid, ed. by Javier del Barco, Serie A: Literatura Hispano-hebrea, 3 vols (Madrid: CSIC, 2003-06), III (2006), pp. 19-53

Pérez, Joseph, La hora de Cisneros (Madrid: Complutense, 1995) 
Raz-Krakotzkin, Amnon, 'Censorship, Editing and the Reshaping of Jewish Identity: The Catholic Church and Hebrew Literature in the Sixteenth Century’, in Hebraica Veritas? Christian Hebraists and the Study of Judaism in Early Modern Europe, ed. by Allison P. Coudert and Jeffrey S. Shoulson (Philadelphia: University of Pennsylvania Press, 2004), pp.125-55

Rekers, Ben, Arias Montano (Madrid: Taurus, 1973)

Revilla Rico, Mariano, La políglota de Alcalá (Madrid: Imprenta Helénica, 1917)

Rummel, Erika, Biblical Humanism and Scholasticism in the Age of Erasmus (Leiden: Brill, 2008)

Sánchez Lora, José Luis, Arias Montano y el pensamiento político en la corte de Felipe II (Huelva: Universidad de Huelva, 2008)

Wilkinson, Robert J., The Kabbalistic Scholars of the Antwerp Polyglot Bible (Leiden: Brill, 2007) 